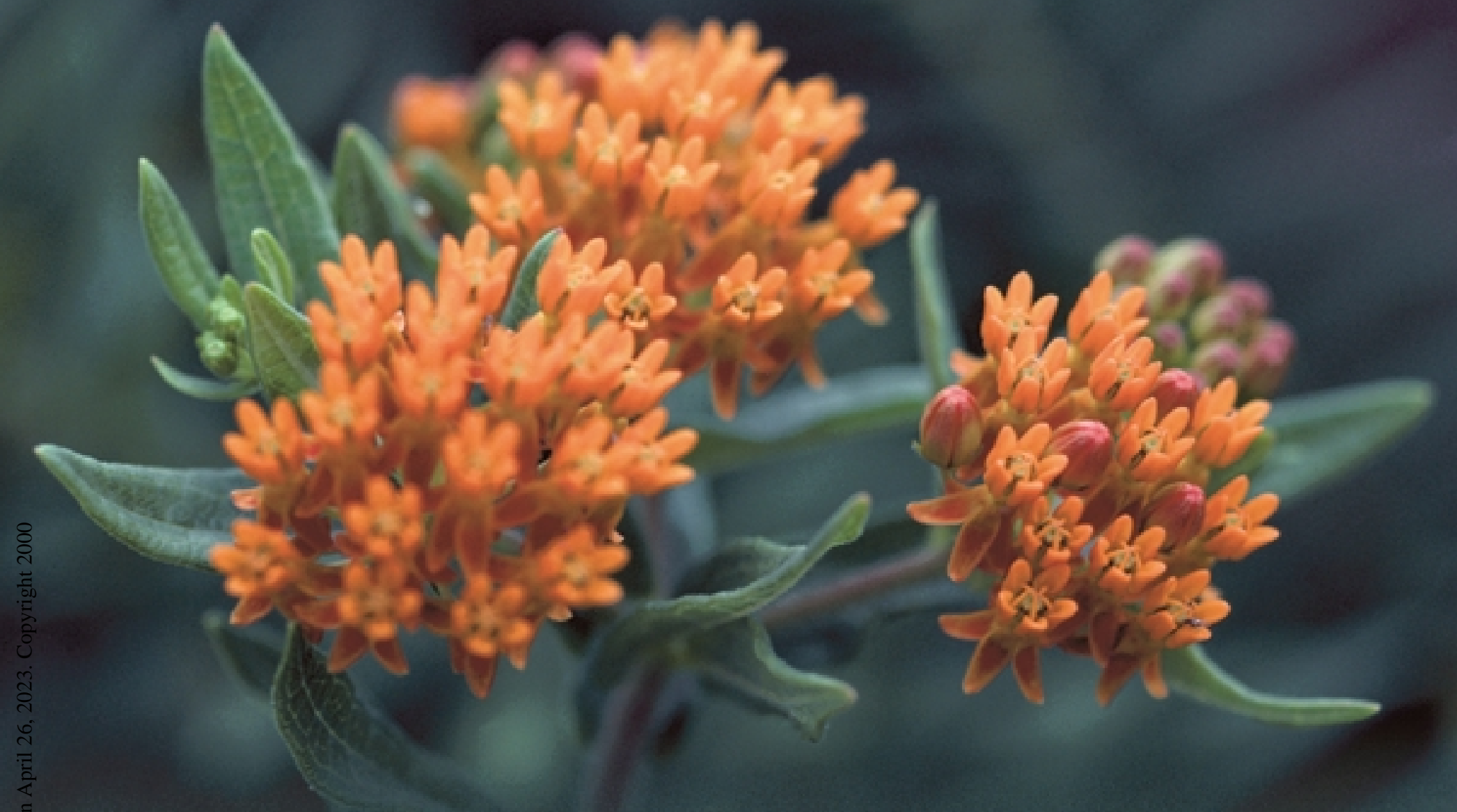

MASON STATE NURSERY: A MODEL FOR

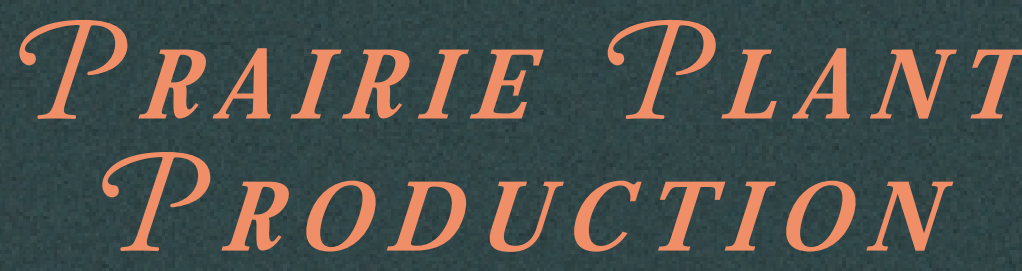

R Kasten D umroese,

St ewart Pequignot,

and David Horvath 


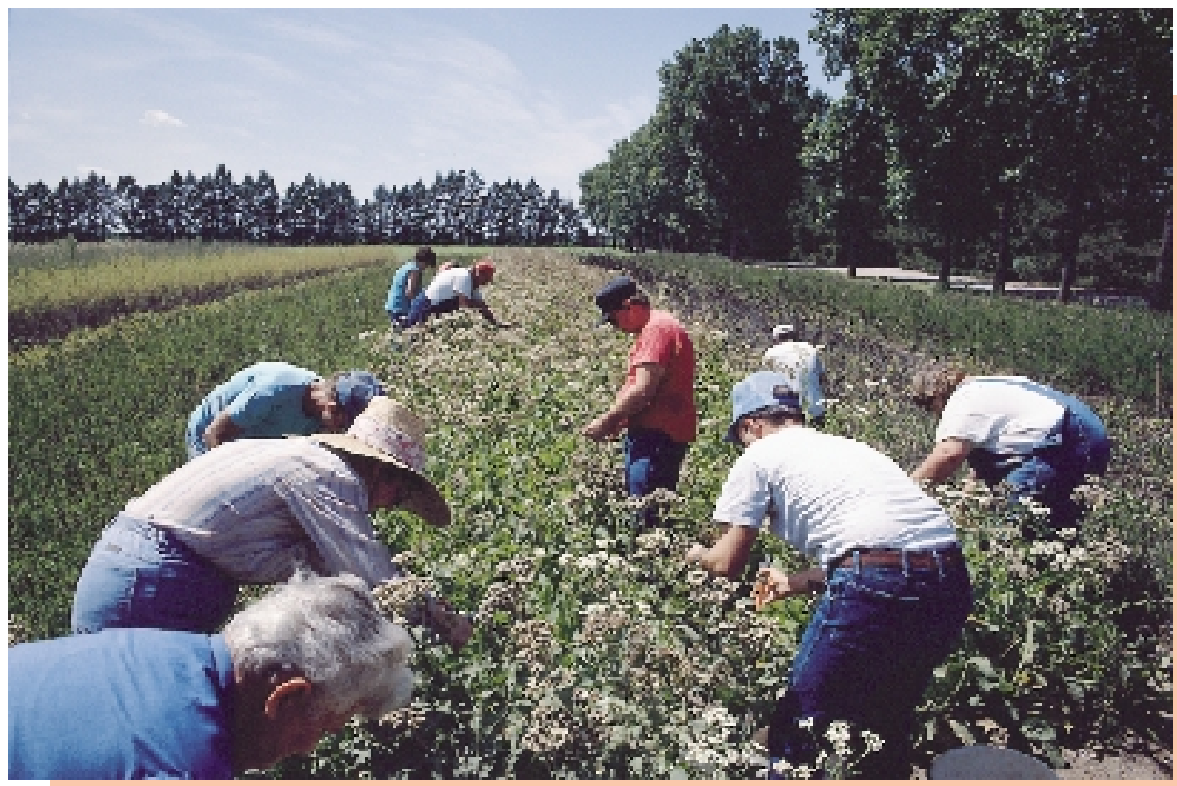

Figure 1 - N ursery workers harvesting wild quinine (Parthenium integrifolium L. [A steraceae]).

\section{A bst ract}

M ore than 250 native Illinois plant species have been grown either bareroot or in containers at $\mathrm{M}$ ason State N ursery. Seedling production is facilitated by collecting seeds from natural populations and by seed production areas at the nursery, and an extensive array of seed processing equipment. Some propagation techniques are included.

KEYWORDS: tall grass prairie, forbs, bareroot nursery, container nursery NOMEN CLATURE: Taft and others (1997) n the 1970s, the Illinois D epartment of $\mathrm{N}$ atural Resources (ID N R) began expanding its activities to protect and manage prairie and other community areas of the state. 0 riginally two-thirds of Illinois was prairie but by the $1960 \mathrm{~s}$ less than $1 \%$ remained, therefore prairie restoration on ID N R lands was an important component of this new direction (Pequignot 1993). ID N R had 2 objectives: 1) establish prairies so citizens and visitors to Illinois could see and appreciate unique prairie communities; and 2) save genetic resources found within Illinois' prairie communities (both plant and animal). In 1977, the ID N R Division of Forest Resources was approached for assistance in establishment of grass seed collection areas because the nursery program had available land for seed collection areas, an experienced work force, and equipment for collecting and processing seed was on site or nearby (Piquignot 1993).

At onset of the prairie program, ID N R envisioned a program growing only 6 grass species, but soon 10 to 12 forbs were added. And addition of new species did not stop there. By 1998, the nursery had grown over 250 species; annually, 50 to 60 prairie species are grown. ID N R defines native plant material as Illinois endemics. Annual production of all plant types may include, depending on seed availability and demand, about 59 native tree and shrub species, 56 prairie forb species, 9 warm season grasses, 21 woodland understory trees, shrubs, and forbs, and 76 wetland species. As the program developed, most notable was the decrease in introduced conifers and shrubs and an increase in native hardwoods (Table 1 ).

TA B LE 1

$\begin{aligned} & \text { Percentages of plant types grown } \\ & \text { at M ason State N ursery } \\ & \text { in 1957 and 1994 }\end{aligned}$
Plant type
Conifers
Shrubs




\section{Seed Collection, Processing, and Storage}

The initial problem with native plant production was lack of seed availability for desired tree, shrub, forb, and grass species, particularly Illinois seed sources. Tree seeds are collected by state biologists, nursery personnel, and the public within 3

TA B LE 2

0 aks (Fagaceae) in seed orchards at the Illinois state nurseries

W hite oak (Q uercus alba $L$.) Swamp white oak ( $Q$. bicolor W illd.) Spanish oak (Q. falcata Michx.) Bur oak (Q . macrocarpa Michx.) $N$ orthern red oak ( $Q$. rubra $L$.) Black oak ( $Q$. velutina Lam.)

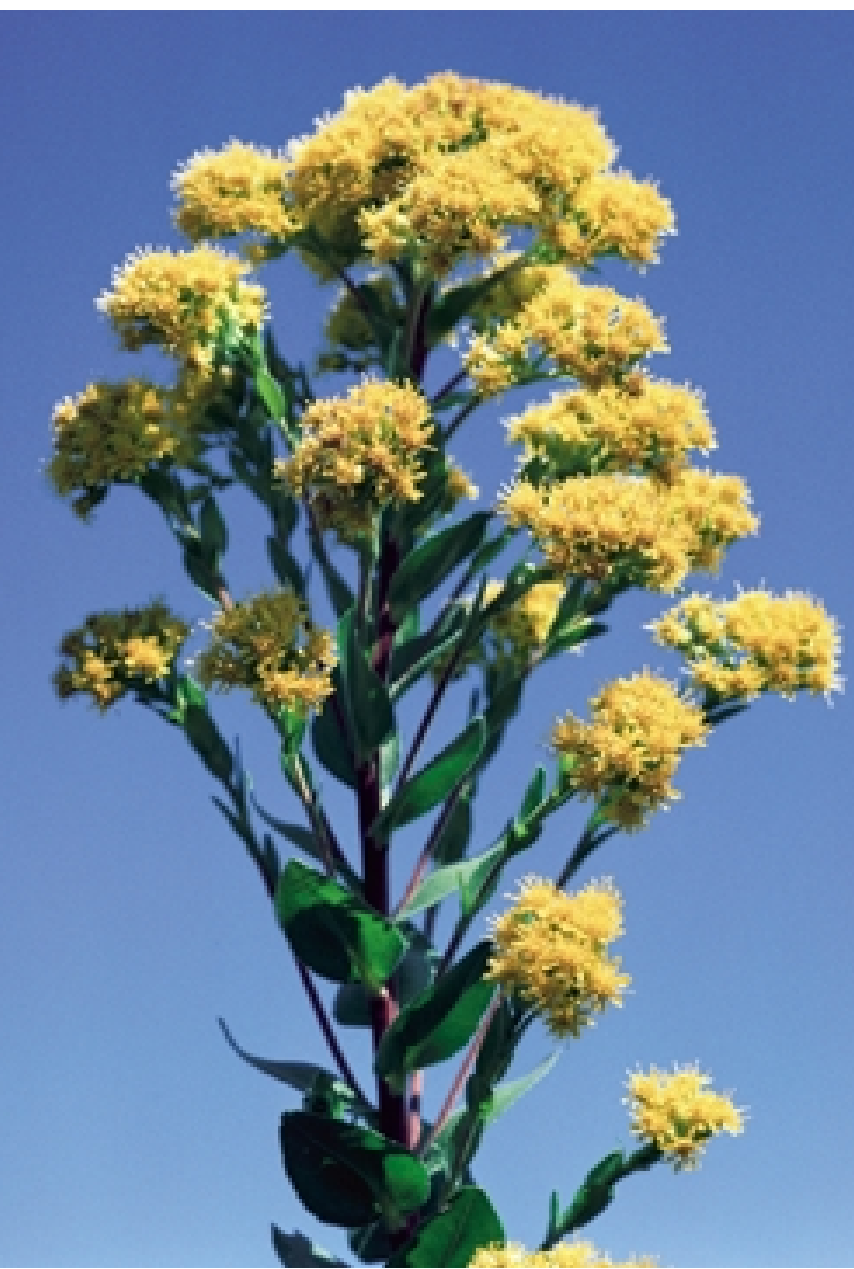

aceae]) and green ash (Fraxinus pennsvlvanica M arsh [O leaceae]).

Shrub seeds were collected, mostly from central and northern Illinois, to get an adequate representation of genotypes. This mixture of genotypes of various shrubs was used to start an on-site 2-ha (5-ac) seed production area that now yields nearly all the seeds used by the $M$ ason State N ursery and its sister, U nion State N ursery.

For prairie plants, early efforts involved ID N R H eritage Biologists and nursery staff collecting seeds from remnant prairie populations. O nce planted at the nursery, bareroot forbs are usually grown $2 \mathrm{y}$. D uring the second season, seeds are harvested for future crops. Seed production from crop plants is augmented by a nearly 3-ha (8-ac) forb seed production area. Around $385 \mathrm{~kg}(850 \mathrm{lb})$ of forb seeds are annually harvested from both seed sources. Although seeds have been harvested with a modified combine, usually seeds are handpicked (Figure 1 ). $\mathrm{H}$ and harvesting is necessary on plants with delicate seeds or uneven height. The main benefit of hand picking is that it reduces the amount of "junk" that would have to otherwise be removed during processing. For most forbs, seeds do not ripen at the same time, so seed heads are allowed to mature and dry in trays before cleaning. Some species, like lance leaf coreopsis (Coreopsis lanceolata L. [Asteraceae]) and yellow coneflower (Ratibida pinnata (Vent.) Barnhart [Asteraceae]), produce seeds over the entire season, so nursery staff pick a median date for harvest. The nursery also established wetland plant seed production areas.

In 1978, the nursery planted 1.2 ha $(3 \mathrm{ac})$ of 5 species of prairie grass. By 1997 over 8 ha ( 20 ac) of seed production area for 9 species were in place, generating over $900 \mathrm{~kg}$ (2000 Ib) of seeds (Table 3). Some prairie seeds, both forb and grass, are still collected off-site for special planting projects.

O nce most of the seeds have dehisced, seeds are further processed on-site with a variety of equipment (Table 4), developed, tested, and modified through years of trial and error and cooperation with the U SD A N ational Seed Tree Laboratory.

Seeds are stored in sealed plastic bags in fiber barrels (have an inner tar paper layer that mice will not chew through) and kept between 0 and $4{ }^{\circ} \mathrm{C}$ ( 32 and $\left.40{ }^{\circ} \mathrm{F}\right)$. Seeds are stored as dry as possible. Viability of most seeds drops off after a couple of years, but it usually does not remain in storage that long before planting. $\mathrm{N}$ ursery staff try to maintain a 2- to 5 -y supply of shrub seed and at least a 1-y supply of forbs to cushion see Prarie Plants on page 14

TA B LE 3

Prairie grass species (Poaceae) in seed production areas at $\mathrm{M}$ ason State $\mathrm{N}$ ursery

Big bluestem (A ndropogon gerardii Vitman)

Side-oats grama (Bouteloua curtipendula (M ichx.) Torr.) Ice cream grass (Eragrostis trichodes (N utt.) Wood)

Prairie switch grass (Panicum virgatum L.)

Little bluestem (Schizachyrium scoparium (M ichx.) N ash) Indian grass (Sorghastrum nutans (L.) N ash)

N orthern dropseed (Sporobolus heterolepis (G ray) G ray) Porcupine grass (Stipa spartea Trin.)

Gama grass (Tripsacum dactyloides (L.) L.) 
Prarie Plants from page 12 against shortfalls and keep some flexibility in planting time.

\section{Greenhouse Production} Greenhouse production is limited to threatened and endangered plants, species with just a few seeds available, grasses for special planting projects, and forbs not grown in bareroot beds because their roots grow so densely the plants cannot be easily lifted (Table 5). Three crops are usually produced, starting with a grass crop sown in late $D$ ecember. Because prairie forbs are warm season plants, crops are germinated in a greenhouse with day tempera- tures of 21 to $27^{\circ} \mathrm{C}$ (70 to $80{ }^{\circ} \mathrm{F}$ ) and night temperatures of 18 to $24^{\circ} \mathrm{C}$ (65 to $75^{\circ} \mathrm{F}$ ). Greenhouse crops are then transitioned through a polyhouse and finally to a shadehouse for hardening.

Forb and wetland seeds require stratification before sowing. Generally equal amounts of seeds and vermiculite are mixed, dampened, and stratified 3 to 4 mo at 1 to $2^{\circ} \mathrm{C}$ ( 34 to $36^{\circ} \mathrm{F}$ ). After dibbling, 3 to 5 seeds are sown into Ropak M ulti-Pot \#6 containers (98 ml [6 in ${ }^{3}$ ] volume, $12 \mathrm{~cm}$ [4.8 in] depth, 581 cavities per $\left.\mathrm{m}^{2}\left[54 / \mathrm{ft}^{2}\right]\right)$ filled with Pro-M ix PGX (3:1; peat moss:vermiculite) amended with 0 smocote plus minors $\left(17 \mathrm{~N}: 6 \mathrm{P}_{2} \mathrm{O}_{5}: 10 \mathrm{~K}_{2} \mathrm{O}\right.$; $\left.4.7 \mathrm{~kg} / \mathrm{m}^{3}\left[5 \mathrm{oz} / \mathrm{ft}^{3}\right]\right)$. The 0 smocote has an 8 to 9 mo release rate at $21^{\circ} \mathrm{C}$ $\left(70^{\circ} \mathrm{F}\right) .0$ smocote fertilizers with faster release rates appear to cause damage to young seedlings, especially grasses. Seeds are covered to $1 X$ their depth with the same medium. Seedlings with their first set of true leaves developed also receive Peters Acid Special $\left(21 \mathrm{~N}: 7 \mathrm{P}_{2} \mathrm{O}_{5}: 7 \mathrm{~K}_{2} \mathrm{O}\right)$ at rates between 50 and 100 ppm N early in the crop cycle (the first 1 to $2 \mathrm{mo}$ ) to supplement the 0 smocote. The rate is gradually increased to 200 ppm N. The top layer of medium is allowed to dry out thoroughly before irrigating. Forbs are thinned to 1 
seedling per cavity before the plants develop extensive root systems. Grasses are not thinned, but are clipped or mechanically mowed back to 10 to $15 \mathrm{~cm}$ (4 to $6 \mathrm{in}$ ) to facilitate irrigation and prevent lodging. Before plants are moved to the polyhouse or shadehouse, fertilizer rates are decreased back to $50 \mathrm{ppm} \mathrm{N}$ and temperatures are reduced to ambient to encourage hardening.

Grasses, forbs, and wetland plants are all grown as a 1-y crop, ready for outplanting in fall. G enerally, nursery staff promote shipping material in the trays. 0 therwise, material is extracted and stored. Forbs must be very dry or else they are susceptible to mold; susceptibility varies by species.

\section{Bareroot Production} Soils at $M$ ason are sandy to sandy loams (52\% to $75 \%$ sand) with generally low fertility and organic matter levels. Bareroot production begins with late summer methylbromide chloropicrin fumigation (390 kg/ha [350 lb/ac]). About 10 ha (25 ac) of tree, shrub, and forb seeds are sown annually during fall to allow natural seed stratification (Table 6). D uring bed formation, winter wheat is mixed in at a rate of $112 \mathrm{~kg} / \mathrm{ha}(100 \mathrm{lb} / \mathrm{ac})$, and then crop seeds are drilled in. Large nuts are sown with custom-made seeders while most other species are drilled with a L ove/ $\varnothing$ yjord seeder. Prairie plant seeds are drilled or planted to a depth $1 X$ their diameter. Wheat germinates and grows during fall, providing seedbed protection, especially from wind erosion. The wheat overstory, by shading soil to keep soil temperatures lower, also prevents germination in early spring when emergents could be damaged by frost. Because wheat can be actively growing throughout the late winter and early spring season, an application of glyphosate (Roundup U Itra; $3.6 \mathrm{I} / \mathrm{ha}$ [1.5 qt/ac]) can be used to kill the wheat and "release" the beds. If crop seeds germinate before wheat can be sprayed, an

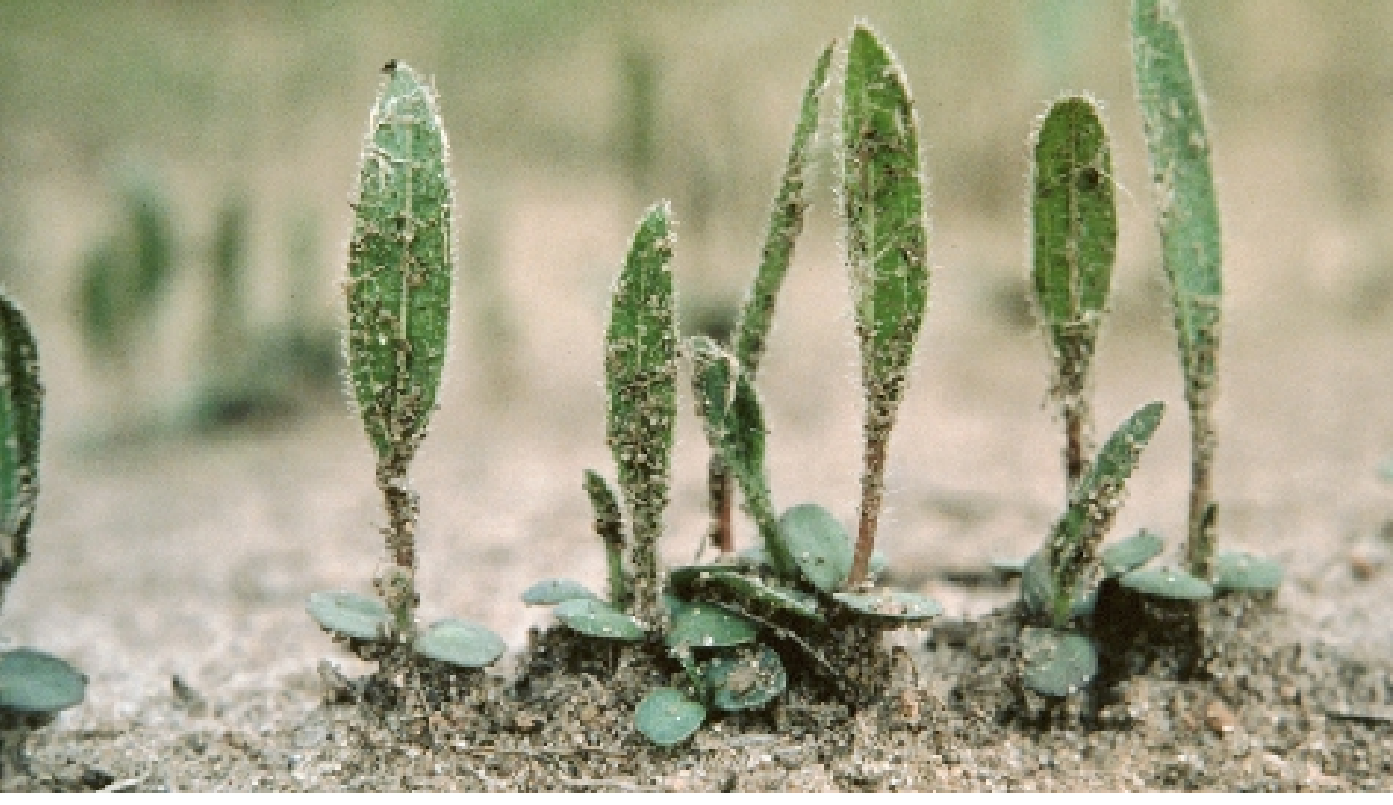

Figure 2 - Echinacea pallida ( $N$ utt.) $N$ utt. (A steraceae) seedlings.

TA B LE 4

Seed processing equipment used for native plant production

\begin{tabular}{lll} 
Equipment & Provider & Description \\
\hline $\begin{array}{l}\text { ALMACO low- } \\
\text { profile thresher } \\
\text { (LPR-UM B-G) }\end{array}$ & $\begin{array}{l}\text { ALMACO } \\
\text { Box 296 }\end{array}$ & $\begin{array}{l}\text { Like a miniature combine, it's the } \\
\text { primary step in cleaning seeds from } \\
\text { small plots. }\end{array}$ \\
\hline $\begin{array}{l}\text { W ESTRUP } \\
\text { brushing }\end{array}$ & W ESTRUP, Inc & $\begin{array}{l}\text { This brush debearder removes } \\
\text { machine }\end{array}$ \\
$\begin{array}{ll}\text { (HA-400) } & \text { Plano, TX 75093 }\end{array}$ & $\begin{array}{l}\text { appendages (wings, hairs, and awns) } \\
\text { from dry seeds. It also reduces clusters } \\
\text { of seeds (maple, ash) into single seeds. } \\
\text { Makes seeds flowable so they can be } \\
\text { further processed. }\end{array}$ \\
\hline
\end{tabular}

Carter Day Carter Day It separates longer particles (needles,

indent seed International, Inc pieces of stems) from shorter particles separator $\quad 500$ Seventy-third (usually seeds).

(N 0.3 Uni-Flow) Ave, NE

Minneapolis, $M \mathrm{~N}$ 55432

\begin{tabular}{|c|c|c|}
\hline $\begin{array}{l}\text { Clipper fanning } \\
\text { mill (A2552) }\end{array}$ & $\begin{array}{l}\text { Clipper } \\
805 \text { South Decker } \\
\text { Drive } \\
\text { Blufton, IN } 46714\end{array}$ & $\begin{array}{l}\text { Separates different sized materials by } \\
\text { using a combination of a fan and a } \\
\text { series of plates with different sized } \\
\text { holes. }\end{array}$ \\
\hline $\begin{array}{l}\text { Crippen fanning } \\
\text { mill } \\
\text { (GX-360-4-RH) }\end{array}$ & $\begin{array}{l}\text { Crippen } \mathrm{Mfg} \mathrm{Co} \text {, } \\
\text { Inc } \\
\text { PO Box } 128 \\
\text { Alma, MI } 48801\end{array}$ & $\begin{array}{l}\text { Seeds and impurities are pushed up } \\
\text { through a chamber in an air stream } \\
\text { provided by a fan. Lighter trash and } \\
\text { empty seeds are removed. }\end{array}$ \\
\hline $\begin{array}{l}\text { Aspirator } \\
(18990)\end{array}$ & $\begin{array}{l}\text { Gene M Jesse Mfg, } \\
\text { Inc } \\
1627 \text { N ord Ave. } \\
\text { Chico, CA } 95926\end{array}$ & $\begin{array}{l}\text { Removes light material from seeds by } \\
\text { drawing a vacuum up a duct. The } \\
\text { system is very powerful but with precise } \\
\text { adjustment it will clean small seeds } \\
\text { (spruces) as well as large seeds (oaks). }\end{array}$ \\
\hline
\end{tabular}

\begin{tabular}{lll}
\hline Dybvig & Melvin Dybvig & Used to burst fleshy fruits. Water \\
macerator & 4025 Rio Vista & washes away the pulp. Can also be \\
& Milwaukee, OR & used to dewing or to break apart dry \\
& 97222 & fruits, but this technique can be dusty
\end{tabular}




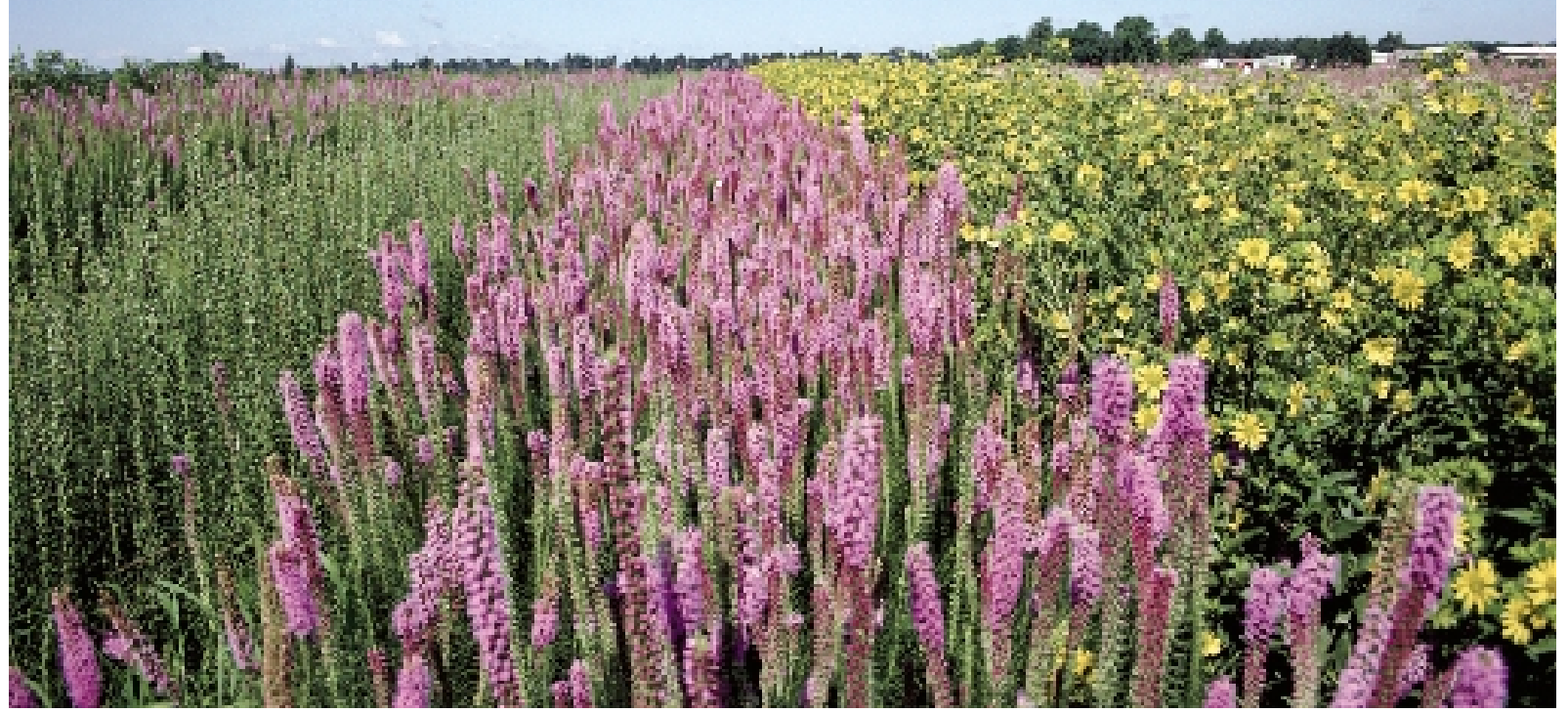

Figure 3 - Bareroot beds of native forbs at Mason State N ursery.

application of fluazifop (Fusilade; $1.2 \mathrm{l} / \mathrm{ha}$ [1 pt/ac]) can be applied.

Trees and Shrubs

All fertilizer is top dressed. Ammonium sulfate $\left(21 \mathrm{~N}: \mathrm{OP}_{2} \mathrm{O}_{5}: \mathrm{OK}_{2} \mathrm{O}\right)$ is applied at $112 \mathrm{~kg} / \mathrm{ha}(100 \mathrm{lb} / \mathrm{ac}) \mathrm{N}$ once a week for 3 wk in $M$ ay or early June, then another 28 to $34 \mathrm{~kg} / \mathrm{ha}$ ( 25 to $30 \mathrm{lb} / \mathrm{ac}$ ) $\mathrm{N}$ is applied weekly for 4 to 6 wk. Q uercus and Juglans species are undercut at $15 \mathrm{~cm}$ ( $6 \mathrm{in})$ when trees are about $25 \mathrm{~cm}$ (10 in) tall to promote lateral roots and keep

TA B LE 5

$\mathrm{N}$ on-indusive list of container-grown prairie forbs and reasons for not growing them bareroot

\begin{tabular}{|c|c|c|c|}
\hline $\begin{array}{l}\text { Threatened and } \\
\text { endangered }\end{array}$ & $\begin{array}{l}\text { Limited seeds } \\
\text { available }\end{array}$ & $\begin{array}{l}\text { Grasses for } \\
\text { special projects }\end{array}$ & $\begin{array}{l}\text { Root too densely } \\
\text { to lift }\end{array}$ \\
\hline $\begin{array}{l}\text { Illinois false aster } \\
\text { (Boltonia } \\
\text { decurrens (Torr. } \\
\& \text { G ray) W ood } \\
\text { [A steraceae]) }\end{array}$ & $\begin{array}{l}\text { Yellow coneflower } \\
\text { (Ratibida pinnata } \\
\text { (Vent.) Barnhart } \\
\text { [A steraceae]) }\end{array}$ & $\begin{array}{l}\text { Prairie switch grass } \\
\text { (Panicum virgatum } \\
\text { L. [Poaceae]) }\end{array}$ & $\begin{array}{l}\text { W ild bergamot } \\
\text { (Monarda } \\
\text { fistulosa L. } \\
\text { [Lamiaceae]) }\end{array}$ \\
\hline $\begin{array}{l}\text { Kankakee } \\
\text { mallow (lliamna } \\
\text { remota G reene } \\
\text { [Malvaceae]) }\end{array}$ & $\begin{array}{l}\text { Prairie alumroot } \\
\text { (Heuchera } \\
\text { richardsonii R. Br. } \\
\text { var. grayana } \\
\text { Rosend., Butt. \& } \\
\text { Lak. [Saxifrag- } \\
\text { aceae]) }\end{array}$ & $\begin{array}{l}\text { Gama grass } \\
\text { (Tripsacum } \\
\text { dactyloides (L.) L. } \\
\text { [Poaceae]) }\end{array}$ & $\begin{array}{l}\text { Pasture rose } \\
\text { (Rosa carolina L. } \\
\text { [Rosaceae]) }\end{array}$ \\
\hline $\begin{array}{l}\text { Royal catchfly } \\
\text { (Silene regia } \\
\text { Sims [Caryophyl- } \\
\text { laceae]) }\end{array}$ & $\begin{array}{l}\text { O bedient plant } \\
\text { (Physostegia } \\
\text { virginiana L. } \\
\text { [Lamiaceae]) }\end{array}$ & $\begin{array}{l}\text { Side-oats grama } \\
\text { (Bouteloua } \\
\text { curtipendula } \\
\text { (M ichx.) Torr. } \\
\text { [Poaceae]) }\end{array}$ & $\begin{array}{l}\text { Partridge pea } \\
\text { (Cassia fasiculata } \\
\text { Michx. [Caesal- } \\
\text { piniaceae]) }\end{array}$ \\
\hline
\end{tabular}

height growth under control. Root pruning is done on cloudy days just after an irrigation. M ost tree species are grown at about 55 seedlings per $\mathrm{m}^{2}\left(5\right.$ per $\left.\mathrm{ft}^{2}\right)$ and as $1+0 \mathrm{~s}$. The exceptions, grown as $2+0$ s, include white oak, pecan (Carya illinoensis Wang. [Juglandaceae]), shagbark hickory (C arya ovata (M ill.) K. Koch), kingnut hickory (Carya laciniosa (M ichx.) Loudon), and red pine (Pinus resinosa Ait [Pinaceae]).

Forbs

Although most forbs (Table 7) can be grown as $1+0$ s, they are usually carried over to the second year so a seed crop can be harvested. Prairie forbs require less fertilizer and irrigation than tree and shrub crops and are usually planted on the "poorest" nursery soils, as long as the soil is well drained. About $56 \mathrm{~kg} / \mathrm{ha}$ (50 lb/ac) of ammonium sulfate are applied 2 or 3 times in $\mathrm{M}$ ay and early June, as well as 1 application of $85 \mathrm{~kg} / \mathrm{ha} \mathrm{K}_{2} \mathrm{O}(75 \mathrm{lb} / \mathrm{ac})$. Forbs are only irrigated to promote germina- 
tion and to wash in top-dressed fertilizers (Figure 2). Prairie forbs are disease free, although some species can be damaged by insects. Seedbed densities range from 44 to 670 seedlings per $\mathrm{m}^{2}$ ( 4 to 60 per $\mathrm{ft}^{2}$ ), depending on species and seed cleanliness (Figure 3 ).

Before lifting, forbs must be dormant, having either experienced a killing frost or an "artificial frost" with paraquat $(2.4 \mathrm{l} / \mathrm{ha}$ [1 qt/ac]) to burn off the foliage. Stems are cut back to the ground. Forbs must be lifted when roots are dry to prevent storage mold problems. Root stocks are placed in plastic bags and kept in refrigerated storage. As with container forbs, nursery staff encourage fall planting to circumvent storage problems.

Forbs are often planted by volunteer crews that sometimes have problems planting stock upside down. D espite this, plantation success is very good. The native prairie plants are much more plastic in terms of pre-planting handling and planting conditions than tree and shrub species.

\section{Understory Plants}

N ursery staff have grown over 20 species of understory plants as part of an emphasis to provide an entire hardwood ecosystem. Because of seed dormancy mechanisms that are difficult to overcome and low demand for seedlings, understory plants are not a large component of annual production. Some of the interesting understory plants grown include pawpaw (Asimina triloba (L.) Dunal [Annonaceae]), cinnamon fern (0 smunda cinnamomea $L$. [O smundaceae]), spicebush (Lindera benzoin (L.) Blume [Lauraceae]), ginseng (Panax quiquefolius $L$. [A raliaceae]), Jack-in-the-pulpit (Arisaema triphyllum (L.) Schott [Araceae]), and may apple (Podophyllum peltatum L. [Berberidaceae]).

\section{Summary}

Augmenting seeds collected from the wild with those from production plants, M ason State N ursery successfully propagates over 250 species of Illinois native plants. The basic propagation techniques are essentially the same as those used to grow the more "traditional" conservation plants, although processing native plant seed requires additional equipment.

\section{Ref erences}

Pequignot SA. 1993. Illinois-an example of how public nurseries can help meet the need for non-traditional plant materials. In: Landis TD, technical coordinator. Proceedings, W estern Forest $\mathrm{N}$ ursery Association; 1992 Sep 14-18; Fallen Leaf Lake, CA. Fort Collins (CO): USDA Forest Service, Rocky Mounta in Forest and Range Experiment Station. G eneral Technical Report RM-221. p 72-77.

Taft JB, W ilhelm GS, Ladd DM, M asters LA. 1997. Floristic quality assessment for vegetation in Illinois, a method for assessing vegetation integrity. Erigenia 15:3-95.
TA B LE 6

Ten commonly grown tree and shrub genera produced as bareroot stock at M ason State N ursery, with the number of species in that genera in parentheses

Hickory-Carya N utt. Juglandaceae (3)

Pine-Pinus L. Pinaceae (3)

Hawthorn-Crataegus L. Rosaceae (1)

0 ak- $Q$ uercus $L$. Fagaceae (16)

Sumac-Rhus L. A nacardiaceae (3)

Plum-Prunus L. Rosaceae (3)

Dogwood-Cornus L. Cornaceae (3)

Redbud-Cercis L. Caesalpiniaceae (1)

Bald cypress-Taxodium Rich. Taxodiaceae (1)

Chokeberry-A ronia Medic. Rosaceae (1)

TA B LE 7

Ten bareroot-grown prairie forbs at M ason State $\mathrm{N}$ ursery

Apiaceae:

Rattlesnake master (Eryngium yuccifolium M ichx.)

\section{Asteraceae:}

Smooth blue aster (A ster laevis L..)

$\mathrm{N}$ ew England aster (Aster novae-angliae L.)

Prairie coreopsis (Coreopsis palmata N utt.)

Rough blazing star (Liatris aspera Michx.)

Prairie blazing star (Liatris pycnostachya Michx.)

Pale purple coneflower (Echinacea pallida (N utt.) N utt.)

$W$ ild quinine (Parthenium integrifolium $L$.)

Yellow coneflower (Ratibida pinnata (Vent.) Barnhart)

W estern sunflower (Helianthus occidentalis Riddell)

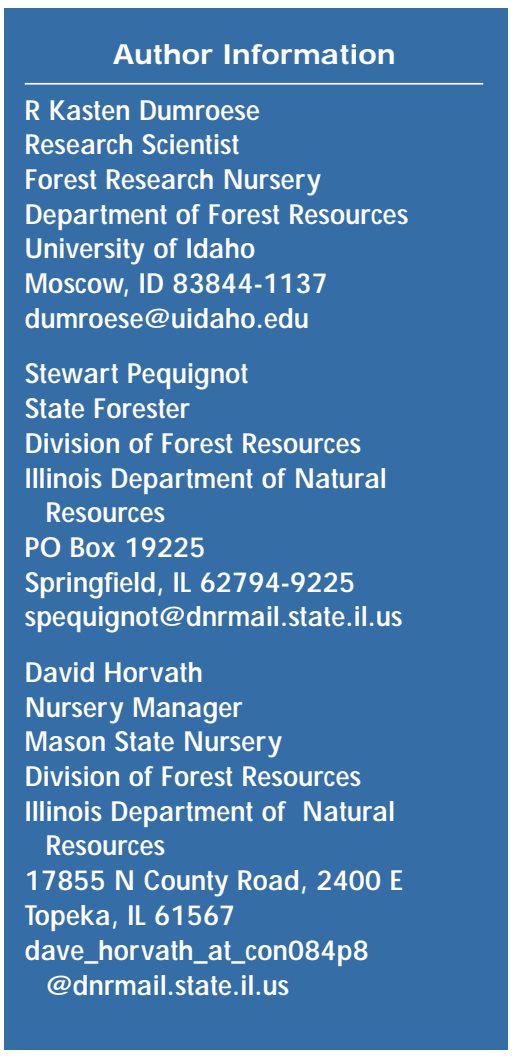

